\title{
Adsorption of rare earth ions onto the cell walls of wild type and lipoteichoic acid-defective strains of Bacillus subtilis
}

\author{
Hiroshi Moriwaki*, Remi Koide, Ritsuko Yoshikawa, Yuya Warabino, \\ Hiroki Yamamoto
}

Shinshu University, Faculty of Textile Science and Technology, Division of Applied Biology, 3-15-1, Tokida, Ueda 386-8567, Japan

* To whom correspondence should be addressed.

E-mail: moriwaki@shinshu-u.ac.jp 


\begin{abstract}
The aim of this study is to investigate the potential of cell walls of wild type and lipoteichoic acid-defective strains of Bacillus subtilis 168 to adsorb rare earth ions. Freeze-dried cell powders prepared from both strains were used for the evaluation of adsorption ability for the rare earth ions, namely, $\mathrm{La}(\mathrm{III}), \mathrm{Eu}(\mathrm{III})$, and $\mathrm{Tm}(\mathrm{III})$. The rare earth ions were efficiently adsorbed onto powders of both wild type strain (WT powder) and lipoteichoic acid -defective strain ( $\triangle$ LTA powder) at $\mathrm{pH} 3$. The maximum adsorption capacities for $\mathrm{Tm}$ (III) by WT and

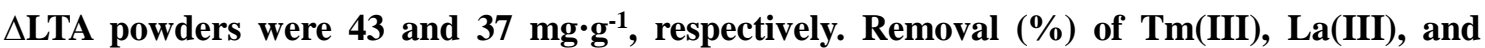
Eu(III) from aqueous solution by WT powder was greater than by $\triangle$ LTA powder. These results indicate that rare earth ions are adsorbed to functional groups, such as phosphate and carboxyl groups, of lipoteichoic acid.

We observed coagulated $\triangle$ LTA powder in the removal of rare earth ions $\left(1-20 \mathrm{mg} \cdot \mathbf{L}^{-1}\right)$ from aqueous solution. In contrast, sedimentation of WT powder did not occur under the same conditions. This unique feature of $\triangle \mathrm{LTA}$ powder may be caused by the difference of the distribution between lipoteichoic acid and wall teichoic acid. It appears that $\Delta$ LTA powder is useful for removal of rare earth ions by adsorption, because aggregation allows for rapid separation of the adsorbent by filtration.
\end{abstract}

Keywords rare earth ion $\cdot$ Bacillus subtilis $168 \cdot$ lipoteichoic acid $\cdot$ lipoteichoic acid-defective strain - adsorbent 


\section{Introduction}

Rare earth metals are widely used in various technological devices, including superconductors, magnets, catalysts, and batteries (Andrianov et al. 2011; Molander and Romero 2002). The global demand for rare earth metals has been increasing (Du and Graedel 2011). There is concern that the increased demand for rare earth metals leads to environmental exposure or water pollution from rare earth metal mines and various commercial products. In one report, high levels of rare earth metals were detected in hair from the scalp of children living in a rare earths mining area in China (Tong et al. 2005). It is known that rare earth metals exhibit hepatotoxic and neurotoxic effects (Pałasz and Czekaj 2000; Basu et al. 1982). Therefore, useful techniques to extract or remove rare earth metal from the environment are needed.

There are many examples of functionalized polymers or phosphates used for the extraction of rare earth ions (Buchmeiser et al. 1998; Sun et al. 2012). However, most of these reagents are expensive and may be toxic themselves. Under these circumstances, it is very important to develop low-cost and environmentally-friendly removal methods for rare earth ions from water.

It is benefical to use bioresource materials as adsorbents for environmental pollutants because of their safety and cost effectiveness. Recently, various bioresource materials have been used as adsorbents for pollutants, such as oil, pesticides, and metal ions (Moriwaki et al. 2009; Senthilkumaar et al. 2010; Ghimire et al. 2003). Bacteria are regarded as effective adsorbents for dissolved metals because of their high surface area per unit weight. Several studies concerned with the adsorption of rare earth ions onto bacterial cells have been conducted (Merroun et al. 2003; Takahashi et al. 2005; Ozaki et al. 2006). It has been suggested that carboxylate and phosphate groups are mainly responsible for the adsorption of rare earth ions onto bacterial cell surfaces (Takahashi et al. 2010). However, more information is needed to clarify the details of the mechanism 
of adsorption of rare earth ions onto bacteria in order to apply them effectively in environmental remediation.

In this study, wild type and lipoteichoic acid-defective strains of Bacillus subtilis 168, which do not produce extracellular polymers such as polyglutamic acid, were investigated for their potential use as adsorbents of rare earth ions. Freeze-dried cell powders prepared from both strains were used for evaluating their ability to adsorb rare earth ions, namely, $\mathrm{La}(\mathrm{III}), \mathrm{Eu}(\mathrm{III})$, and $\mathrm{Tm}(\mathrm{III})$.

Teichoic acids are bacterial polysaccharides that consist of glycerol phosphate or ribitol phosphate. These polyphosphate compounds constitute a major component of the cell wall in most gram-positive bacteria, including Bacillus subtilis. Teichoic acids come in 2 distinct forms depending on whether they are linked to the head groups of membrane lipids (lipoteichoic acids: LTAs) or to the wall peptidoglycan (wall teichoic acids: WTAs) (Neuhaus et al. 2003). Peptidoglycan is also major structural compound in the cell walls of bacteria. The contribution of LTAs to the adsorption of rare earth ions onto bacterial cells is not clear, although it has been reported that phosphates on the cell wall contribute to the process (Takahashi et al. 2010). By comparing the adsorption of rare earth ions onto the cell surfaces of wild type and lipoteichoic acid-defective strains, it was expected that the role of LTAs in the adsorption of rare earth ions onto the bacterial cell walls could be further elucidated.

\section{Materials and methods}

Reagents

Nitric acid, manganese(II) sulfate, iron(II) sulfate, lanthanum(III) chloride, europium(III) chloride, and thulium(III) chloride were purchased from Wako Pure Chemical Industries (Osaka, Japan). 
Distilled water was produced by an automatic water distillation apparatus (WG203; Yamato Scientific, Tokyo, Japan).

Construction of the mutant strains

The strains of B. subtilis and Escherichia coli, and plasmids used in this study are listed in Table 1. All chemical reagents were purchased from Wako Pure Chemical Industries (Osaka, Japan) unless otherwise noted. B. subtilis 168 was used as the parent strain throughout the study. B. subtilis strains were grown in Luria Bertani (LB) medium (Sambrook et al. 1989) at $37^{\circ} \mathrm{C}$. To culture a quadruple mutant of the ltaS paralogous genes (RY1604), erythromycin was added to final concentrations of $0.30 \mu \mathrm{g} \mathrm{mL}{ }^{-1}$. E. coli strains harboring plasmids were cultured in $\mathrm{LB}$ medium at $37^{\circ} \mathrm{C}$, and ampicillin was added to a final concentration of $100 \mu \mathrm{g} \mathrm{mL}^{-1}$. DNA manipulations and $E$. coli transformation were performed by standard methods (Sambrook et al. 1989). The conventional transformation method (Anagnostopoulos and Spizizen 1961) was used for B. subtilis transformation.

Primers used in this study are listed in Table 2. After the polymerase chain reaction (PCR)-amplified fragments were digested with restriction enzymes purchased from Takara (Kyoto, Japan), all DNA fragments were separated by $1 \%$ agarose gel electrophoresis and purified with QIAquick gel extraction kit (QIAGEN) according to the manufacturer's instructions.

To construct a triple mutant for $y f n I, y q g S$, and $y v g J$ without any antibiotic resistance markers, we used an efficient allelic replacement method with pMAD (Arnaud et al. 2004). For the construction of pMAD $\Delta y f n I$, upstream $(530 \mathrm{bp})$ and downstream $(509 \mathrm{bp})$ regions of the $y f n I$ gene were amplified with 2 sets of primers, yfnIf-Bf and yfnIf-PEr, and yfnIb-ESf and yfnIb-NKr, respectively, and 168 chromosomal DNA (chrDNA) as a template. The amplified fragments were digested with EcoRI. The fragments were then ligated and the ligation mixture was used as a 
template for a $2^{\text {nd }}$ PCR with yfnIf-Bf and yfnIb-NKr. After digestion with BamHI and NcoI, the resulting 1.0-kb DNA fragment was cloned into the corresponding sites in pMAD to obtain pMAD $\Delta y f n I$. Similar procedures were used to construct pMAD $\Delta y q g S$ and pMAD $\Delta y v g J$. For pMAD $\Delta y q g S$, primers used for the upstream (510 bp) and downstream (511 bp) fragments were yqgSf-Bf and yqgSf-PEr, and yqgSb-ESf and yqgSb-NKr, respectively. For pMAD $\Delta y$ vgJ, primers used for the upstream (508 bp) and downstream (519 bp) fragments were yvgJf-Bf and yvgJf-Pr, and yvgJb-PSf and yvgJb-NKr, respectively. The amplified fragments were digested with PstI. Then the fragments were ligated and the ligation mixture was used as a template for a $2^{\text {nd }} \mathrm{PCR}$ with yvgJf-Bf and yvgJb-NKr. After the amplified 1.0-kb fragment was digested with BamHI and NcoI, the fragment was cloned into the corresponding sites in pMAD to obtain pMAD $\Delta y \mathrm{vgJ}$. After sequencing the inserts of these pMAD-derivatives, the plasmids were used for transformation of E. coli C600 to generate concatemeric DNAs.

For the construction of an IPTG-inducible ltaS-conditional mutant, the 5'-terminal region, including the ribosome-binding site, was amplified by PCR using 168 chrDNA as the template, and primers yflE-SD-EF and yflE-p2-BR. The amplified 311-bp fragment was digested with EcoRI and BamHI, and the resultant fragment was cloned into the corresponding sites of pMUTIN4 (Vagner et al. 1998) to obtain pM4 4 NyflE. After sequencing the insert DNA fragment, the plasmid was used for transformation of E. coli $\mathrm{C} 600$ to generate a concatemeric DNA.

The sources of donor DNAs and recipient cells used for B. subtilis mutant construction are listed in Table 1. To construct a triple null mutant of $y f n I, y q g S$ and $y v g J, B$. subtilis RY1603, without any antibiotic resistance genes, we used an efficient allelic replacement method, step by step, with pMAD-derived plasmids (Arnaud et al. 2004). First, to construct a $y v g J$ null mutant ( $\Delta \mathrm{yvgJ}), B$. subtilis 168 was transformed with pMAD $\Delta \mathrm{yvgJ}$. A blue colony was selected on LB plates containing $0.3 \mu \mathrm{g} \cdot \mathrm{mL}^{-1}$ of erythromycin and $200 \mu \mathrm{g} \cdot \mathrm{mL}^{-1}$ of $\mathrm{X}$-gal (5-bromo-4-chloro-3- 
indolyl- $\beta$-D-galactopyranoside). We performed the subsequent integration and excision procedures as described by Arnaud et al. (2004). After the excision procedure, we selected some white and erythromycin-sensitive colonies to obtain $B$. subtilis $\Delta y \mathrm{ygJ}$. We then confirmed the proper null mutation at the $y v g J$ locus by PCR with primers YvgJ-up and YvgJ-down. Next, B. subtilis $\Delta y v g J$ was transformed with pMAD $\Delta \mathrm{yqgS}$ to obtain a $y v g J$ yqgS double null mutant, B. subtilis RY1602. After integration and excision procedures, we checked the proper null mutation at the $y q g S$ locus by PCR with primers YqgS-up and YqgS-down. Finally, B. subtilis RY1602 was transformed with pMAD $\Delta y f n I$ to obtain a triple null mutant of $y f n I, y q g S$ and $y v g J$, B. subtilis RY1603. After integration and excision procedures, we checked the proper null mutation at the $y f n I$ locus by PCR with primers YfnI-up and YfnI-down.

For construction of an ltaS-conditional mutant, B. subtilis 168 was transformed with pM4 4 NyflE to obtain $B$. subtilis LTASp. After selection on LB agar plates containing erythromycin $\left(0.30 \mu \mathrm{g} \cdot \mathrm{mL}^{-1}\right)$ and IPTG $(1 \mathrm{mM})$, appropriate integration of the plasmid DNA at the ltaS locus was confirmed by PCR. To obtain a quadruple mutant of the ltaS paralogous genes (RY1604), B. subtilis RY1603 was transformed with LTASp chrDNA as a donor DNA. The resulting transformants were selected on LB agar plates containing erythromycin $\left(0.30 \mu \mathrm{g} \cdot \mathrm{mL}^{-1}\right)$ and IPTG $(1.0 \mathrm{mM})$. We subsequently confirmed the proper mutations of four loci (ltaS, yfnI, yqgS and yvgJ) by PCR. In addition, after the inducer (IPTG) was removed, we also confirmed that the quadruple mutant cells exhibited slow growth and aberrant filamentous clumps twisted around their long axis as described previously (Schrner et al. 2009).

Preparation of WT and $\Delta$ LTA powder

B. subtilis strains were cultured in $6 \mathrm{~mL}$ of $\mathrm{LB}$ medium at $30^{\circ} \mathrm{C}$ over night. When a quadruple 
mutant of the ltaS paralogous genes (RY1604) was first cultured, erythromycin and IPTG were added to final concentrations of $0.30 \mu \mathrm{g} \cdot \mathrm{mL}^{-1}$ and $1.0 \mathrm{mM}$, respectively. Cells corresponding to 1 $\mathrm{mL}$ of the cultures were harvested by centrifugation (Tabletop centrifuge-CT15RE, Hitachi Koki, Tokyo, Japan) and washed once with $1 \mathrm{~mL}$ of fresh $\mathrm{LB}$ medium to remove the inducer. The cells were then inoculated at an $\mathrm{OD}_{600}$ of 0.001 into $1 \mathrm{~L}$ of fresh $\mathrm{LB}$ medium. After incubation for $3 \mathrm{~h}$ at $37^{\circ} \mathrm{C}$, LTA-deficient cells were harvested by centrifugation (himac CR21, Hitachi Koki, Tokyo, Japan). The cell pellet was suspended with $30 \mathrm{~mL}$ of ultrapure water and boiled for $20 \mathrm{~min}$. After cooling, cells were precipitated by centrifugation (himac CR21, Hitachi Koki, Tokyo, Japan), washed once with $30 \mathrm{~mL}$ of ultrapure water, and freeze-dried. Then, the solid materials were crushed with a medicine spoon and sieved. The diameter of the powders ranged from 53 to $100 \mu \mathrm{m}$. Powders from the wild type strain (WT powder) and the lipoteichoic acid-defective strain ( $\triangle$ LTA powder) were obtained.

The powders were visualized using a scanning electron microscope (SEM; JSM-6010LA; JEOL, Tokyo, Japan). The samples were sputtered with platinum using a JFC-1600 instrument (JEOL, Tokyo, Japan).

Adsorption test

The general procedure for evaluating the removal of Tm(III), $\mathrm{La}(\mathrm{III}), \mathrm{Eu}(\mathrm{III}), \mathrm{Fe}(\mathrm{II})$, or $\mathrm{Mn}$ (II) using WT powder or $\triangle$ LTA powder as a sorbent was as follows: $20 \mathrm{mg}$ of WT powder or $\Delta$ LTA powder was added to $20 \mathrm{~mL}$ of a metal ion solution $\left(20 \mu \mathrm{g} \cdot \mathrm{mL}^{-1}, \mathrm{pH} 3\right)$ in a conical flask. It is known that rare earth ions form complexes with hydroxide or carbonate at $\mathrm{pH}$ greater than approximately 5.5 (Liu and Byrne, 1998). In order to keep rare earth metals as free cations, the $\mathrm{pH}$ level of the tested solutions was set at 3 for the adsorption test. The suspensions were mixed for $30 \mathrm{~min}$ at $10 \mathrm{rpm}$ and 
then filtered with filter paper (suspended particle size: $7 \mu \mathrm{m}$; No. 5A, Advantec, Tokyo, Japan). The adsorption (\%) of a metal ion to the membrane was below $10 \%$ under the experimental condition. The filtrate was centrifuged at $4000 \mathrm{rpm}$ (Tabletop centrifuge-2410, Kubota Corporation, Tokyo, Japan) for $20 \mathrm{~min}$. A $5.0 \mathrm{~mL}$ aliquot of the supernatant was added to $5 \mathrm{~mL}$ of nitric acid, and heated. The resulting solution was diluted with distilled water to a final volume of $20 \mathrm{~mL}$, and then quantitatively analyzed for the metal ion concentration using inductively coupled plasma atomic emission spectrometry.

The adsorption capacities of the WT and $\Delta$ LTA powder for Tm(III) were determined in the original Tm(III) solution under various conditions. All experiments were conducted at $25{ }^{\circ} \mathrm{C}$ in thermostatic chamber.

Analytical procedure

Metal ion concentrations in solutions were measured by inductively coupled plasma (ICP) atomic emission spectrometer (SPS 3100; SSI nanotechnology, Tokyo, Japan) under the following experimental operating conditions: RF power, $1.2 \mathrm{~kW}$; plasma gas flow rate $(\mathrm{Ar}), 16 \mathrm{~L} \cdot \mathrm{min}^{-1}$; carrier gas flow rate, $1.0 \mathrm{~L} \cdot \mathrm{min}^{-1}$; auxiliary gas flow rate, $1.0 \mathrm{~L} \cdot \mathrm{min}^{-1}$. Working wavelengths for iron, manganese, lanthanum, europium, and thulium were 260.569, 259.940, 379.478, 412.970, and $313.126 \mathrm{~nm}$. The limits of quantification for $\mathrm{Mn}(\mathrm{II}), \mathrm{Fe}(\mathrm{II}), \mathrm{La}(\mathrm{III}), \mathrm{Eu}(\mathrm{III})$, and $\mathrm{Tm}(\mathrm{III})$ were 5, 2, 5, 7 and $3 \mathrm{ng} \cdot \mathrm{mL}^{-1}$, respectively.

\section{Results}

WT and $\Delta$ LTA powders 
The surfaces of WT and $\triangle$ LTA powders were examined by SEM. Typical rod-shaped cells were observed in WT powder and slightly curved ones were found in $\triangle$ LTA powder, and it was confirmed that the structure of the cell walls was not disrupted by the preparation of the powders. Furthermore, it was determined that there were no significant differences in the surface areas between the WT and $\Delta$ LTA powders because the conformations of the surfaces were very similar. The powders were shaken in water for $30 \mathrm{~min}$, filtered, dried, and reevaluated by SEM (Fig.1 for $\triangle$ LTA powder). No changes in shape of the powders were observed after shaking in aqueous solution for $30 \mathrm{~min}$.

Removal of rare earth metal ions by WT or $\triangle \mathrm{LTA}$ powder

The adsorptive removals of $\mathrm{La}(\mathrm{III}), \mathrm{Eu}(\mathrm{III}), \mathrm{Tm}(\mathrm{III}), \mathrm{Mn}(\mathrm{II})$, and $\mathrm{Fe}(\mathrm{II})$ by the cell walls were studied in order to assess the extraction ability of the $B$. subtilis powders. The results are shown in Table 3.

The removal $(\%)$ of rare earth ions from aqueous solution $\left(20 \mu \mathrm{g} \cdot \mathrm{mL}^{-1}\right)$ with WT or $\Delta \mathrm{LTA}$ powder as the adsorbent were $>60 \%$ (entries 1,2 , and 4 in Table 3 ). On the other hand, the removal (\%) of $\mathrm{Fe}(\mathrm{II})$ and $\mathrm{Mn}(\mathrm{II})$ were $<24 \%$ (entries 7 and 8 ). The percentage of $\mathrm{Tm}$ (III) removed was higher than the percentage of $\mathrm{Fe}(\mathrm{II})$ removed from the Fe(II) and $\mathrm{Tm}$ (III) binary solution. This suggests that $\mathrm{Tm}(\mathrm{III})$ was selectively removed by the $B$. subtilis powders (entries 9 and 10). These results indicate that the $B$. subtilis powders are effective adsorbents for rare earth ions.

The removal $(\%)$ of rare earth ions increased in the order of atomic number $(\mathrm{La}(\mathrm{III})<\mathrm{Eu}(\mathrm{III})<$ Tm(III), entries 1, 2, and 4). As atomic number increases, the radius of each lanthanide ion (III) steadily decreases (lanthanide contraction), and electron affinity increases. Because of this feature of rare earth ions, the adsorptive association of heavy rare earth ions to the adsorbents would be greater 
than that of light rare earth ions. Takahashi et al.(2010) have reported similar patterns of adsorption of rare earth ions by cell walls of gram-positive bacteria.

The removal (\%) of metal ions by WT powder was greater than by $\Delta$ LTA powder. This result indicates that lipoteichoic acid contributes to the adsorption of rare earth ions onto the cell wall of $B$. subtilis. Furthermore, without LTA, the removal (\%) of the rare earth ions was greater than that of $\mathrm{Fe}(\mathrm{II})$ and $\mathrm{Mn}(\mathrm{II})$ at $\mathrm{pH}$ 3. This indicates that WTA contributes to the adsorption of rare earth ions onto cell walls. It is well known that the cell wall of B. subtilis consists of peptidoglycan (65\%) and teichoic acid (35\%). However, the abundance ratios of LTA and WTA in B. subtilis 168 have not been clarified. Therefore, the contribution ratio to the adsorption of rare earth ions by LTA and WTA could not be quantified at this stage.

The effect of changing the duration of shaking on the adsorption of Tm(III) by the B. subtilis powders was studied in order to determine the equilibration time for adsorption (Fig. 2). The percentages of $\mathrm{Tm}$ (III) removed were 91 and $74 \%$ for WT and $\Delta$ LTA powders, respectively, and barely changed by varying the duration of shaking from 1 to $300 \mathrm{~min}$. These results suggest that this method of adsorption does not require long equilibration times, and can therefore be used for the rapid removal of $\mathrm{Tm}(\mathrm{III})$ from water. The rapid removal of $\mathrm{Tm}(\mathrm{III})$ by the B. subtilis powders may be related to their high surface area per unit weight.

Next, the recovery of adsorbed Tm(III) by the powders was observed. WT or $\Delta$ LTA powder (20 $\mathrm{mg}$ ) was added to $20 \mathrm{~mL}$ of $\mathrm{La}(\mathrm{III}), \mathrm{Eu}(\mathrm{III})$ or $\mathrm{Tm}(\mathrm{III})$ solution $\left(20 \mu \mathrm{g} \cdot \mathrm{mL}^{-1}, \mathrm{pH} 3\right)$, mixed for 30 min at $10 \mathrm{rpm}$ and filtered with $5 \mathrm{~A}$ filter paper. The used filter was eluted by nitric acid (2.7 M, 20 $\mathrm{mL}, 2$ times), and the concentrations of rare earth ions in the eluates were analyzed. The total recoveries of adsorbed rare earth ions were $>94 \%$ for both WT and $\Delta$ LTA powders. This result indicates that rare earth ions in water can be extracted by adsorption to the powders and eluted with nitric acid. 
Coagulation sedimentation of $\triangle$ LTA powder

The $\Delta$ LTA powder readily coagulated and sedimented in the presence of rare earth ions at $20 \mu \mathrm{g} \cdot \mathrm{mL}^{-1}$ (Fig. 3). On the other hand, such coagulation and sedimentation did not occur with WT powder and rare earth ion aqueous solution under the same conditions. The times required for the filtration of the test solution ( $20 \mathrm{~mL}$ ) by 5 A filtration paper were 105 and 43 seconds for the WT powder and $\Delta$ LTA powder, respectively. This result suggests that $\Delta$ LTA powder is useful for the extraction of rare earth ions from water. The $\Delta$ LTA powder coagulates and sediments in the presence of $\mathrm{Tm}(\mathrm{III})$ at $1.0-200 \mu \mathrm{g} \cdot \mathrm{mL}^{-1}$.

\section{Discussion}

$\mathrm{La}(\mathrm{III}), \mathrm{Eu}(\mathrm{III})$, and $\mathrm{Tm}(\mathrm{III})$, but not $\mathrm{Fe}(\mathrm{II})$ or $\mathrm{Mn}(\mathrm{II})$, were removed effectively from water by WT and $\triangle$ LTA powder. It has been reported that cadmium ion adsorb preferentially onto phosphate groups of the B. subtilis cell walls at $\mathrm{pH}$ values lower than 4.5 , and that the contribution of carboxylate groups increases as $\mathrm{pH}$ increases (Boyanov et al. 2003). In the present study, the contribution of phosphate groups to the adsorption of rare earth ions would be high because the adsorption activity was studied at $\mathrm{pH} 3$. The unique properties of rare earth ions are their strong Lewis acidity and their affinity toward hetero atoms, such as oxygen. It is well known that rare earth ions interact with phosphate groups. It is thought that the adsorption of rare earth ions onto the oxygen atom of the phosphate group is more powerful than that of $\mathrm{Fe}(\mathrm{II})$ or $\mathrm{Mn}$ (II). That would cause the selective adsorption of rare earth ions onto the cell walls. When the adsorption of $\mathrm{Mn}$ (II) to the WT powder was studied at $\mathrm{pH} 5$, the carboxyl group was easily ionized, and the removal (\%) of Mn(II) was 75\%. This result supports the ideas described above. 
In order to evaluate the adsorption capacities the B. subtilis powders for Tm(III), the obtained adsorption data were fitted to the Langmuir and Freundlich adsorption isotherm equations. The adsorption of Tm(III) onto the WT or $\Delta$ LTA powder powders could be fitted well to Langmuir as well as Freundlich models (all $\mathrm{r}^{2}$ values were $>0.97$ ), and the adsorption mechanism of Tm(III) to the powders could not be discussed by using these adsorption isotherm equations. Here, we focused on the Langmuir constants of the B. subtilis powders. The parameters obtained from the Langmuir isotherm of the B. subtilis powders are summarized in Table $\mathbf{4}$ along with the parameters obtained from the Langmuir isotherm of adsorbents, which have been previously reported. The B. subtilis powders had a maximum uptake capacity $\left(\mathrm{q}_{\mathrm{e}}\right)$ of 43.1 and $36.9 \mathrm{mg} \cdot \mathrm{g}^{-1}$ for WT powder and $\Delta \mathrm{LTA}$ powder, respectively. The maximum uptake capacities of the B. subtilis powders for $\mathrm{Tm}(\mathrm{III})$ were comparable to those of other adsorbents for rare earth ions listed in Table 4. The $\mathrm{K}_{\mathrm{L}}$ value of the $B$. subtilis powders for $\mathrm{Tm}(\mathrm{III})$ was also similar to those of the other adsorbents.

The difference of the coagulation and sedimentation properties between the WT powder and $\Delta$ LTA powder could be caused by the different distribution of teichoic acids. It is reported that LTA is a major component of the B. subtilis periplasm (Matias and Beveridge 2008), and it is believed that LTA localizes at the inner site of cell walls compared to WTA. In the case of $\triangle$ LTA powder, rare earth ions are adsorbed to WTA, which is located on the outer surface of the cell wall. That causes the interaction between $\triangle$ LTA powders to increase, and the aggregation to accelerate. On the other hand, in the WT powders, the rare earth ions adsorb to WTA and LTA. Therefore, compared to $\triangle$ LTA powder, coagulation sedimentation of WT powder is not likely to occur. The aggregation of WT powder occurred in solutions with $\mathrm{Tm}(\mathrm{III})$ concentrations greater than $50 \mu \mathrm{g} \cdot \mathrm{mL}^{-1}$. This result supports the proposed mechnaism of the aggregation of the $\Delta$ LTA powder at lower levels of rare earth ions compared to the WT powder.

In conclusion, a novel application for the cell walls of wild type and lipoteichoic acid-defective 
strains of $B$. subtilis 168 has been presented in this study. The procedure of culturing these $B$. subtilis strains has been well established, and it is not difficult to produce the powders described herein as adsorbent materials.

The comparison between the powders obtained from these B. subtilis strains revealed that lipoteichoic acid contributes to the adsorption of rare earth ions onto the cell walls of B. subtilis. In addition, we showed the novel finding, that in the presence of rare earth ions, the $\Delta$ LTA powder coagulates and sediment more easily than the WT powder.

It is anticipated that the B. subtilis powders could be useful not only for the removal of rare earth ions from environmental or waste water, but also for their extraction as valuable resources. The powders make several potential contributions to the development of water cleanup technology and environmental sciences.

The next step of this work is to investigate the potential of the cell walls of wall-teichoic acid -defective strains as adsorbents for rare earth ions and to understand the contribution of wall-teichoic acid to the adsorption of rare earth ions onto the cell wall.

Acknowledgement This work was supported by Shinshu University Satellite Venture Business Laboratory (SVBL). We wish to thank Mrs. Keiko Kakegawa (SVBL) for her generous SEM measurement. A part of this work was supported by Grants-in-Aid for Scientific Research (C) (19580085 and 23580107) and grants from the Kurata Memorial Hitachi Science and Technology Foundation, the Nagase Science and Technology Foundation, and the Research Foundation for the Electrotechnology of Chubu to H.Y.

\section{References}

Anagnostopoulos C, Spizizen J (1961) Requirements for transformation in Bacillus subtilis. J. 
Bacteriol. 81: 741-746

Andrianov AV, Savel'eva OA, Bauer E, Staunton JB (2011) Squeezing the crystalline lattice of the heavy rare earth metals to change their magnetic order: Experiment and ab initio theory. Phys. Rev. B. 84: 132401

Arnaud M, Chastanet A, Débarbouillé M (2004) New vector for efficient allelic replacement in naturally nontransformable, low-GC-content, Gram-positive bacteria. Appl. Environ. Microbiol. 70: $6887-6891$

Basu A, Chakrabarty K, Chatterjee GC (1982) Neurotoxicity of lanthanum chloride in newborn chicks. Toxicol. Lett. 14: 21-25

Boyanov MI, Kelly SD, Kemner KM, Bunker BA, Fein JB, Fowle DA (2003) Adsorption of cadimium to Bacillus subtilis bacterial cell walls: a $\mathrm{pH}$-dependent $\mathrm{X}$-ray absorption fine structure spectroscopy study. Geochim. Cosmochim. Acta 67: 3299-3312

Buchmeiser MR, Tessadri R, Seebar G, Bonn GK (1998) Selective extraction of rare earth elements from rocks using a high-capacity cis-1,4-butanedioic acid functionalized resin. Anal. Chem. 70: $2130-2136$

Chen Y, Zhu B, Wu D, Wang Q, Yang Y, Ye W, Guo J (2012) Eu(III) adsorption using di(2-thylhexly)phosphoric acid-immobilized magnetic GMZ bentonite. Chem. Eng. J. 181-182: $387-396$

Du X, Graedel TE (2011) Global in-use-stocks of the rare earth elements: A first estimate. Environ. Sci. Technol. 45: 4096-4101

Ghimire KN, Inoue K, Yamaguchi H, Makino K, Miyajima T (2003) Adsorptive separation of arsenate and arsenite anions from aqueous medium by using orange waste. Water Res. 37: $4945-4953$

Hang Y, Qin Y, Jiang Z, Hu B (2002) Direct analysis of trace rare earth elements by fluorination 
$\begin{array}{llllll}\text { assisted ETV-ICP-AES with slurry sampling through nano-sized } \mathrm{TiO}_{2} & \end{array}$ separtion/preconcentration. Anal. Sci. 18: 843-846

Liu Z, Byrne RH (1998) Comprehensive investigation of yttrium and rare earth element complexation by carbonate ions using ICP-mass spectrometry. J. Solution Chem. 27: 803-815

Matias VRF, Beveridge TJ (2008) Lipoteichoic acid is a major component of the Bacillus subtilis periplasm. J. Bacteriol. 190: 7414-7418

Merroun ML, Chekroun KL, Arias JM, González-Munoz MT (2003) Lanthanum fixation by Myxococcus xanthus: cellular location and extracellular polysaccharide observation. Chemosphere 52: 113-120

Molander GA, Romero JAC (2002) Lanthanocene catalysts in selective organic synthesis. Chem. Rev. 102: 2161-2185

Moriwaki H, Kitajima S, Kurashima M, Hagiwara A, Haraguchi K, Shirai K, Kanekatsu R, Kiguchi K (2009) Utilization of silkworm cocoon waste as a sorbent for the removal of oil from water. J. Hazard. Mater. 165: 266-270

Neuhaus FC, Baddiley J (2003) A continuum of anionic charge: structures and functions of D-alanyl-teichoic acids in gram-positive bacteria. Microbiol. Mol. Biol. Rev. 67: 686

Ozaki T, Suzuki Y, Nankawa T, Yoshida T, Ohnuki T, Kimura T, Francis AJ (2006) Interactions of rare earth elements with bacteria and organic ligands. J. Alloys Compd. 408-412: 1334-1338

Pałasz A, Czekaj P (2000) Toxicological and cytophysiological aspects of lanthanides action. Acta Biochim. Polonica 47: 1107-1114

Sambrook J, Fritsch EF, Maniatis T (1989) Molecular Cloning: A Laboratory Manual. Cold Spring Harbor, NY: Cold Spring Harbor Laboratory Press

Schirner K, Marles-Wright J, Lewis RJ, Errington J (2009) Distinct and essential morphogenic functions for wall- and lipoteichoic acids in Bacillus subtilis. EMBO J. 8: 830-842 
Senthilkumaar S, Krishna SK, Kalaamani P, Subburamaan CV, G.-Subramaniam N (2010) Adsorption of organophosphorous pesticide from aqueous solution using "waste" Jute fiber carbon. Modern Appl. Sci. 4: 67-83

Sert Ş, Kütahyali C, İnan S, Talip Z, Çetinkaya B, Eral M (2008) Biosorption of lanthanum and cerium from aqueous solutions by Platanus orientalis leaf powder. Hydrometallurgy 90: 13-18

Sun X, Luo H, Dai S (2012) Solvent extraction of rare earth ions based on functionalized ionic liquids. Talanta 90: 132-137

Takahashi Y, Châtellier X, Hattori KH, Kato K, Fortin D (2005) Adsorption of rare earth elements onto bacteria cell walls and its implication for REE sorption onto natural microbial mats. Chem. Geol. 219: 53-67

Takahashi Y, Yamamoto M, Yamamoto Y, Tanaka K (2010) EXAFS study on the cause of enrichment of heavy REE on bacterial cell surfaces. Geochim. Cosmochim. Acta 74: 5443-5462

Tong SL, Zhu WZ, Gao ZH, Meng YX, Peng RL, Lu GC (2005) Distribution characteristics of rare earth elements in children's scalp hair from a rare earths mining area in southern china. J. Envoron. Sci. Health A 39: 2517-2532

Vagner V, Dervyn E, Ehrlich D (1998) A vector for systematic gene inactivation in Bacillus subtilis. Microbiology 144: 3097-3104

\section{Figure captions}

Fig.1 Scanning electron micrographs of $\triangle$ LTA powders after shaking in water for 30 minutes followed by drying.

Fig. 2 Effect of duration of shaking on Tm(III) removal (\%) by WT and $\Delta$ LTA powders.

(WT powder: $\square$; $\Delta$ LTA powder: $\circ$; Initial Tm(III) concentration: $20 \mu \mathrm{g} \cdot \mathrm{mL}^{-1} ; \mathrm{pH}=3$; adsorbent load: $20 \mathrm{mg} / 20 \mathrm{~mL}$ ) 
Fig.3 Photograph of the solution containing Tm(III) and the Bacillus subtilis cell powders (right: WT; left: $\Delta$ LTA) after shaking for 30 minutes.

(Initial Tm(III) concentration: $20 \mu \mathrm{g} \cdot \mathrm{mL}^{-1} ; \mathrm{pH}=3$; adsorbent loading: $20 \mathrm{mg} / 20 \mathrm{~mL}$ ) 
Table 1. Bacterial strains and plasmids used in this study.

\begin{tabular}{|c|c|c|}
\hline Strain and plasmid & Relevant genotype & Source $^{*}$ or Reference \\
\hline \multicolumn{3}{|l|}{ Bacillus subtilis } \\
\hline 168 & $\operatorname{trp} C 2$ & S. D. Ehrlich \\
\hline$\Delta y v g J$ & $\operatorname{trp} C 2 \Delta y v y J$ & pMAD $\Delta \mathrm{yvgJ}_{\rightarrow} 168$ \\
\hline RY1602 & $\operatorname{trp} C 2 \Delta y v y J \Delta y q g S$ & $\mathrm{pMAD} \Delta \mathrm{yqgS} \rightarrow \Delta \mathrm{yvgJ}$ \\
\hline RY1603 & $\operatorname{trpC} 2 \Delta y v y J \Delta y q g S \Delta y f n I$ & pMAD $\Delta y f n I \rightarrow R Y 1602$ \\
\hline LTASp & trpC2 ltaS'::lacZ lacI bla erm $C \mathrm{P}_{\text {spac }}$-ltaS & $\mathrm{pM} 4 \Delta \mathrm{NyflE} \rightarrow 168$ \\
\hline RY1604 & $\begin{array}{l}\operatorname{trp} C 2 \Delta y v y J \Delta y q g S \Delta y \text { fnI ltaS'::lacZ lacI bla } \\
\text { erm } C \mathrm{P}_{\text {spac }} \text {-ltaS }\end{array}$ & LTASp $\rightarrow$ RY 1603 \\
\hline \multicolumn{3}{|l|}{ Escherichia coli } \\
\hline JM109 & 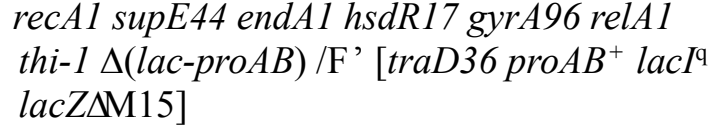 & TaKaRa \\
\hline C600 & $\begin{array}{l}\text { supE44 hsdR17 thi-1 thr-1 leuB } 6 \text { lacY1 } \\
\text { tonA21 }\end{array}$ & Laboratory stock \\
\hline \multicolumn{3}{|l|}{ Plasmids } \\
\hline pMAD & bla erm C bgaB & Arnaud et al., 2004 \\
\hline pMAD $\Delta y f n I$ & bla ermC bgaB $\triangle y f n I$ & This study \\
\hline pMAD $\Delta y q g S$ & bla ermC bgaB $\triangle y q g S$ & This study \\
\hline pMAD $\Delta y v g J$ & bla ermC bgaB $\triangle y v g J$ & This study \\
\hline pMUTIN4 & lacZ lacI bla ermC & Vagner et al., 1998 \\
\hline $\mathrm{pM} 4 \Delta \mathrm{NyflE}$ & $\begin{array}{l}\text { pMUTIN4:: } \Delta l t a S \text { (containing ltaS } \\
\text { Shine-Dalgarno sequence) }\end{array}$ & This study \\
\hline
\end{tabular}

* : Sources shown before and after the arrows indicate donor DNA and recipient cells on transformation, respectively. 
Table 2. Primers used in this study.

\begin{tabular}{|c|c|c|}
\hline Primer & Sequence $\left(5^{\prime} \rightarrow 3^{\prime}\right)^{*}$ & Restriction site \\
\hline yfnIf-Bf & gccggatccTACGCTAAGGATGTCTGG & BamHI \\
\hline yfnIf-PEr & gcgaattcctgcagCAGTATAACAGCCAGCAC & EcoRI \\
\hline yfnIb-ESf & gcgaattcccgggCCGTTGATCCGTCAGAC & EcoRI \\
\hline yfnIb-NKr & gccggtaccatggTCAGGCTGTTGTGCTTCC & NcoI \\
\hline YfnI-up & GGCTGAGACATCTGCAG & \\
\hline YfnI-down & CCCAGCATCTGTACCTC & \\
\hline yqgSf-Bf & gccggatccTGTCAGCGCGAGATGTG & BamHI \\
\hline yqgSf-PEr & gcgaattcctgcagATACGTTTTCAGCCACATC & EcoRI \\
\hline yqgSb-ESf & gcgaattcccgggACCAGAAAAGGCTGGAC & EcoRI \\
\hline yqgSb-NKr & gccggtaccatggCTTCAGCTCCCAGATAGG & NcoI \\
\hline YqgS-up & TGCTAAAAAGACGACACG & \\
\hline YqgS-down & TGACGCGTTCATATGGAC & \\
\hline yvgJf-Bf & gccggatccATACCCGATATCTGCCAC & BamHI \\
\hline yvgJf-Pr & gcgctgcagCATAAAAACCGCTGATTGTG & Pst $\mathrm{I}$ \\
\hline yvgJb-PSf & cggctgcagaggcctAATGGTGACCTGCTCAGG & Pst $\mathrm{I}$ \\
\hline yvgJb-KNr & gccggtaccatggATCAATGTCGTTCTCCGC & NcoI \\
\hline YvgJ-up & GCTTATGGCTGCGTCAG & \\
\hline YvgJ-down & AAACGGATTTTGACAGGTG & \\
\hline yflE-SD-EF & gcgcgaattcCGTTTCGCTCGAACTGGAT & EcoRI \\
\hline yflE-p2-BR & gcgcggatccTGTAGTACACAATGTTGG & BamHI \\
\hline
\end{tabular}

*: The additional sequence (lowercase) and restriction site (under line) are indicated. 
Table 3 Removal (\%) of metal ions from water ${ }^{\mathrm{a}}$ using the Bacillus subtilis powders

\begin{tabular}{ccccc}
\hline \multirow{2}{*}{ Entry } & \multirow{2}{*}{ Adsorbate } & Initial conc. & \multicolumn{2}{c}{ Removal (\%) } \\
\cline { 4 - 5 } & & $\left(\mu \mathrm{g} \mathrm{mL}^{-1}\right)$ & WT powder & $\Delta$ LTA powder \\
\hline 1 & $\mathrm{La}(\mathrm{III})$ & 20 & 78 & 62 \\
2 & $\mathrm{Eu}(\mathrm{III})$ & 20 & 89 & 74 \\
3 & $\mathrm{Tm}(\mathrm{III})$ & 10 & 96 & 95 \\
4 & $\mathrm{Tm}(\mathrm{III})$ & 20 & 90 & 74 \\
5 & $\mathrm{Tm}(\mathrm{III})$ & 50 & 59 & 46 \\
6 & $\mathrm{Tm}(\mathrm{III})$ & 100 & 35 & 29 \\
7 & $\mathrm{Fe}(\mathrm{II})$ & 20 & 24 & 17 \\
8 & $\mathrm{Mn}(\mathrm{II})$ & 20 & 24 & 17 \\
9 & $\mathrm{Tm}(\mathrm{III})+\mathrm{Fe}(\mathrm{II})$ & 20 ea. & $89(\mathrm{Tm}), 5.3(\mathrm{Fe})$ & $76(\mathrm{Tm}), 8.1(\mathrm{Fe})$ \\
10 & $\mathrm{Tm}(\mathrm{III})+\mathrm{Fe}(\mathrm{II})$ & 50 ea. & $54(\mathrm{Tm}), 3.3(\mathrm{Fe})$ & $43(\mathrm{Tm}), 4.0(\mathrm{Fe})$ \\
\hline
\end{tabular}

${ }^{\mathrm{a}} \mathrm{The} \mathrm{pH}$ value of the test solution was set at $\mathrm{pH}$. The adsorbent $(20 \mathrm{mg})$ was added to the aqueous solutions (20 mL). 


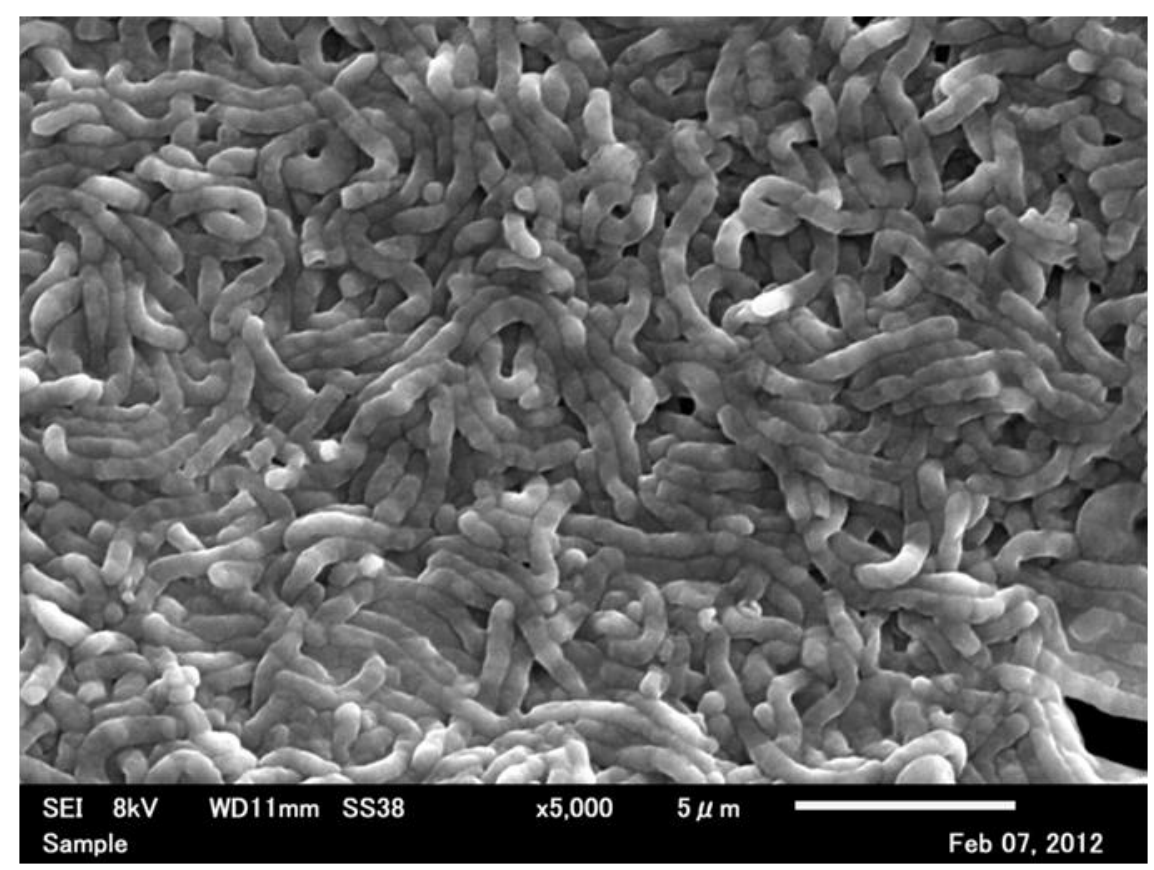

Fig.1 


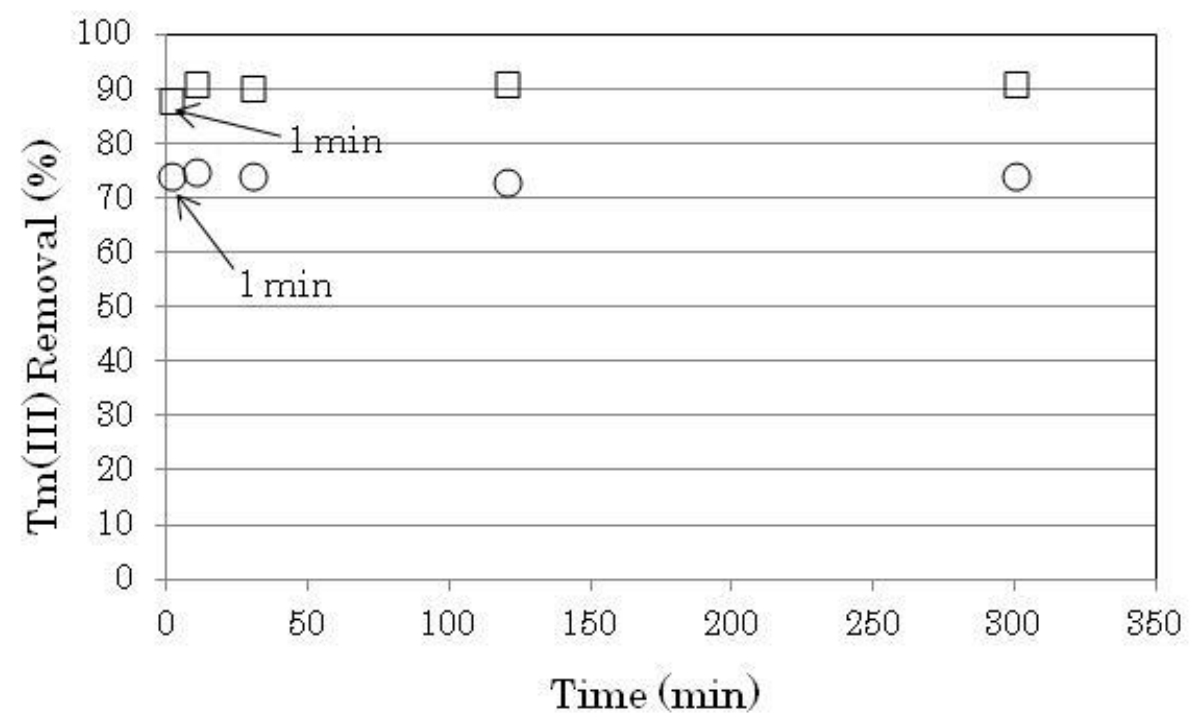

Fig. 2 


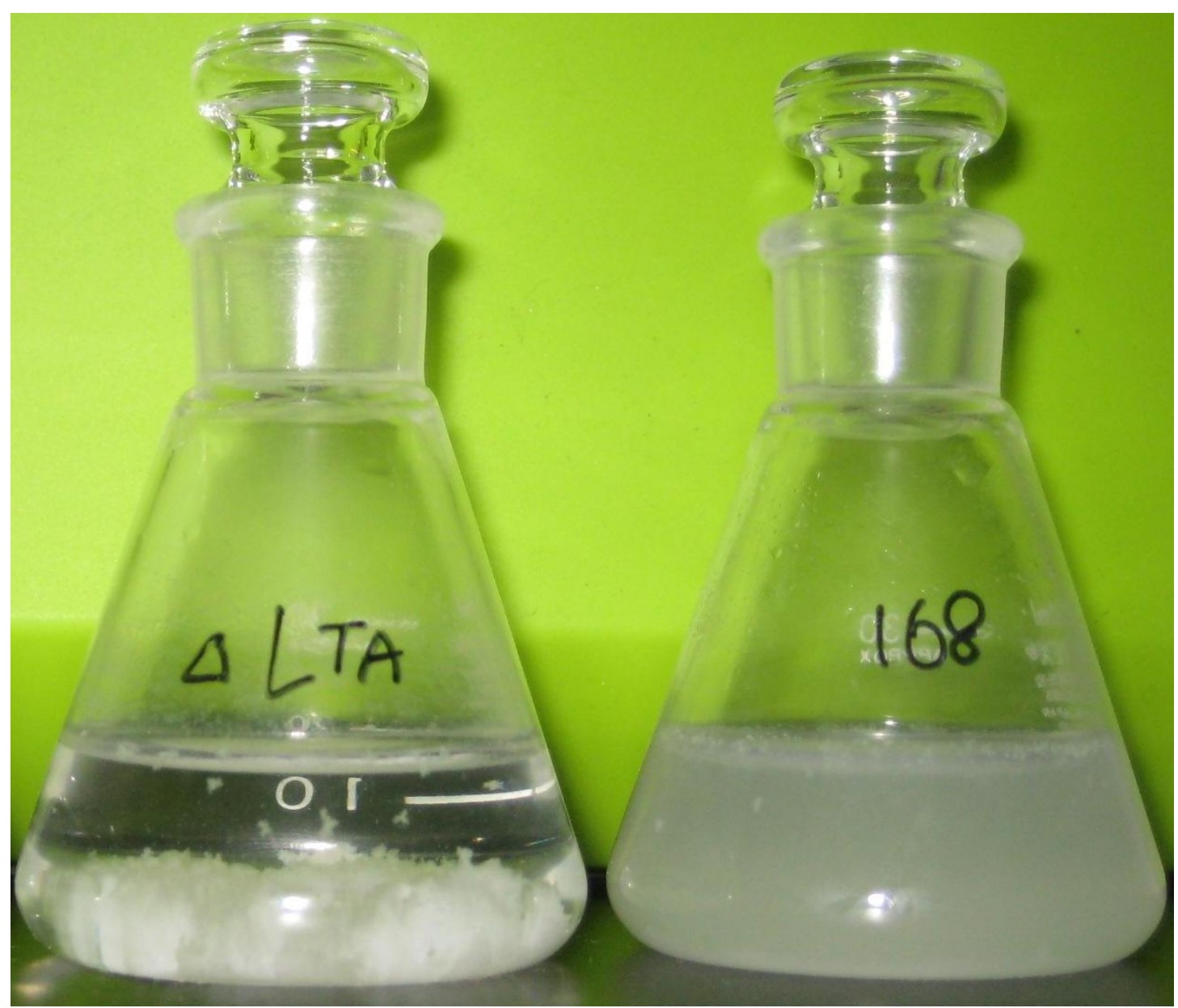

Fig. 3 